\title{
MODELING THE RADIATION SHIELDING OF BORON NEUTRON CAPTURE THERAPY BASED ON 2.4 MeV D-D NEUTRON GENERATOR FACILITY
}

\author{
Muhammad Mu'Alim ${ }^{1}$, Yohannes Sardjono ${ }^{2}$ \\ ${ }^{1}$ Faculty of Engineering - Gadjah Mada University, Jln. Grafika 2 Yogyakarta, 55281 \\ ${ }^{2}$ Centre for Accelerator Science and Technology - National Nuclear Energy Agency, Jl. Babarsari Kotak \\ Pos 6101 Ykbb, Yogyakarta, 55281 \\ Diterima editor: 2 September 2017 \\ Diperbaiki: 17 Januari 2018 \\ Disetujui untuk publikasi: 17 Januari 2018
}

\begin{abstract}
MODELING THE RADIATION SHIELDING OF BORON NEUTRON CAPTURE THERAPY BASED ON 2.4 MEV D-D NEUTRON GENERATOR FACILITY. Radiation shield at Boron Neutron Capture Therapy (BNCT) facility based on D-D Neutron Generator $2.4 \mathrm{MeV}$ has been modified with pre-designed beam shaping assembly (BSA). Modeling includes the material and thickness used in the radiation shield. This radiation shield is expected to protect workers from radiation doses rate that is not exceed $20 \mathrm{mSv}$.year-1 of dose limit values. The selected materials are barite, paraffin, polyethylene and lead. Calculations were performed using the MCNPX program with tally F4 to determine the dose rate coming out of the radiation shield not exceeding the radiation dose rate of $10 \mu \mathrm{Sv} \cdot \mathrm{hr}-1$. Design 3 was chosen as the recommended model of the four models that have been made. The 3rd shield design uses a $100 \mathrm{~cm}$ thickness of barite concrete as primamary layer to surrounding $100 \mathrm{~cm} \times 100 \mathrm{~cm} \times 166.4 \mathrm{~cm}$ room, and a $40 \mathrm{~cm}$ borated polyethylene surrounding the barite concrete material. Then $10 \mathrm{~cm}$ barite concrete and $10 \mathrm{~cm}$ of borated polyethylene are added to reduce the primary radiation straight from the BSA after leaving the main layer. The largest dose rate was $4.58 \mu \mathrm{Sv} \cdot \mathrm{h}-1$ on cell 227 and average radiation dose rate $0.65 \mu \mathrm{Sv} \cdot \mathrm{hr}-1$. The dose rates are lower than the lethal dose that is allowed by BAPETEN for radiation worker lethal dose.
\end{abstract}

Keywords: Radiation shield, tally, radiation dose rate, BSA, BNCT

\begin{abstract}
ABSTRAK
PEMODELAN PERISAI RADIASI PADA FASILITAS BORON NEUTRON CAPTURE THERAPY BERBASIS GENERATOR NEUTRON D-D 2,4 MeV. Telah dimodelkan perisai radiasi pada fasilitas Boron Neutron Capture Therapy (BNCT) berbasis reaksi D-D pada Neutron Generator 2,4 MeV dengan Beam Shaping Assembly (BSA) yang telah didesain sebelumnya. Pemodelan ini dilakukan untuk memperoleh suatu desain perisai radiasi untuk fasilitas BNCT berbasis generator neutron 2,4 MeV. Pemodelan dilakukan dengan cara memvariasikan bahan dan ketebalan perisasi radiasi. Bahan yang dipilih adalah beton barit, parafin, polietilen terborasi dan timbal. Perhitungan dilakukan menggunakan program MCNPX dengan tally F4 untuk menentukan laju dosis yang keluar dari perisai radiasi. Desain periasi radiasi dinyatakan optimal jika radiasi yang dihasilkan diluar perisai radiasi tidak melebihi Nilai Batas Dosis (NBD) yang telah ditentukan oleh BAPETEN. Hasilnya, diperoleh suatu desain perisai radiasi menggunakan lapisan utama beton barit setebal $100 \mathrm{~cm}$ yang mengelilingi ruangan $100 \mathrm{~cm} \times 100$ $\mathrm{cm} \times 166,4 \mathrm{~cm}$ dan polietilen terborasi $40 \mathrm{~cm}$ yang mengelilingi bahan beton barit. Kemudian ditambahkan beton barit $10 \mathrm{~cm}$ dan polietilen terborasi $10 \mathrm{~cm}$ untuk mengurangi radiasi primer yang lurus dari BSA setelah keluar dari lapisan utama. Laju dosis terbesar adalah 4,58 $\mu \mathrm{Sv} \cdot j a \mathrm{~m}-1$ pada sel 227 dan laju dosis rata-rata yang dihasilkan adalah sebesar 0,65 $\mu$ Sv vjam-1. Nilai laju dosis tersebut masih dibawah ambang batas NBD yang diperbolehkan oleh BAPETEN untuk pekerja radiasi.
\end{abstract}

Kata kunci: Perisai radiasi, tally, laju dosis radiasi, BSA, BNCT

DOI: $10.17146 / \mathrm{tdm} .2018 .20 .1 .3633$ 


\section{INTRODUCTION}

Cancer is a dangerous disease caused by the growth of a mass of cells that is unnatural and uncontrollable. According to the World Health Organization (WHO), the world population died annually of cancer reaches 8.2 million people or an estimated $13 \%$ of all deaths worldwide [1]. In Indonesia, the GLOBOCAN estimated in 2012, for all ages and both sexes, the numbers of incidence and mortality of brain cancer reached 3402 and 4902 [2], respectively. It makes Indonesia becomes the first rank in the Southeastern Asia. Therefore, the need for more effective novel treatments for this disease is very urgent [3]. The Boron Neutron Capture Therapy (BNCT) can be a possible solution.

BNCT has been considered as a potential method for cancer treatment $[4,5,6,7]$. BNCT is one of the radiation therapy techniques that use ${ }^{10} \mathrm{~B}$ non-radioactive nuclides to capture neutron and then generate nuclear reaction ${ }^{10} \mathrm{~B}(\mathrm{n}, \alpha){ }^{7} \mathrm{Li}$. The product of this reaction has a high linear energy transfer (LET) (particles $\alpha$ is about $150 \mathrm{keV} \mu \mathrm{m}-1)$. The trace length of these particles in air or tissue is about $4.5 \mathrm{~cm}-10 \mu \mathrm{m}$; therefore, energy transfer is limited to cell diameter only. Theoretically, tumor cells can be selectively irradiated by ${ }^{10} \mathrm{~B}$ without affecting the surrounding healthy cells. The nuclear reactions that occur can be seen in Figure 1 [8].

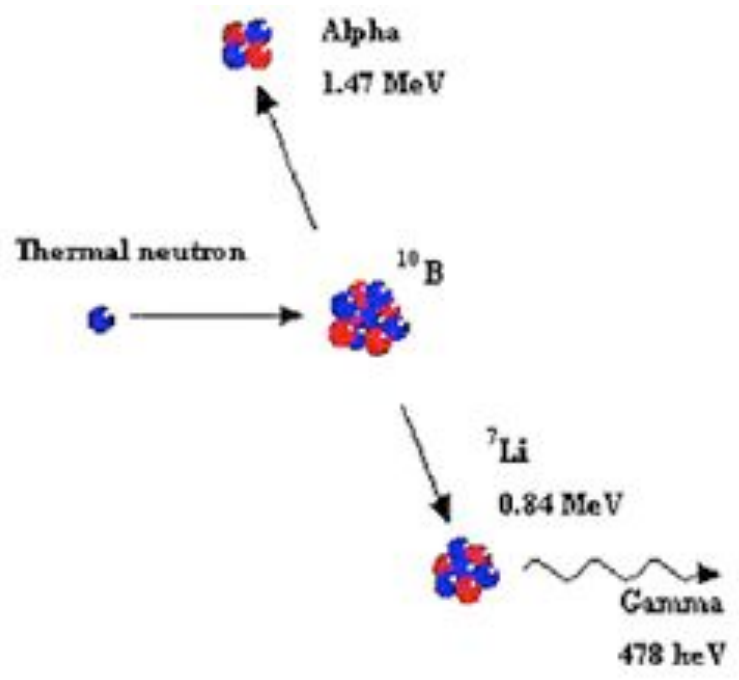

Figure 1. Schematic Interaction between Neutron and Boron [8].

Various studies have been conducted by The Indonesian Consortium of BNCT such as Boron carrier pharmaceutical preparations, neutron sources for BNCT, and also shielding design for BNCT Facility $[9,10,11]$. In this study, we have modeled a shielding design for BNCT facility room especially for BNCT based on 2.4 MeV D-D Neutron Generator. Various studies have been conducted to find out the optimal design for BNCT shielding. Radiation shields for the Cyclotron $30 \mathrm{MeV}$ BNCT facility have been modeled. This modeling includes the selection of materials and the determination of the thickness of the shield. This shield is required to hold the radiation out of the room so that the radiation leakage dose is below the dose threshold for radiation workers of 20 mSv.year-1 [12]. Modeling the radiation shielding for Kartini Reactor BNCT facility with a neutron source from Kartini reactor thermal column using MCNPX has been conducted. The selected materials are stainless steel, barit concrete, paraffin and borated polyethyene. This study could be one of the references for selection of radiation shielding materials and the geometry design of the treatment room [13].

A research has been undertaken on the selection of radiation shielding materials for BNCT treatment rooms based on D-T neutron sources using ordinary concrete as primary shields and polyethylene as a secondary shielding facility for electron or proton therapy at the Shohadaye Tajrish hospital. This study aims to find the geometry and thickness of each main wall, secondary 
wall, entrance, maze, and window monitor at BNCT treatment facility using MCNP-4C code [14]. It is such a possible way to build up a BNCT based on D-D Neutron Generator $2.4 \mathrm{MeV}$ system for cancer treatment $[15,16]$. Therefore, it is needed to find out the optimal design for BNCT shielding based on $2.4 \mathrm{MeV}$ D-D Neutron Generator that will be constructed using local components which are available in Indonesia. The tested materials are lead, paraffin, barite concrete, and borated polyethylene. All the simulation studies were calculated using tally facility on the MCNPX program.

\section{METHODOLOGY}

This research consists of three steps: modeling treatment room; shielding material variations; and dose calculations. The first step was started by modeling the BNCT facility based on $2.4 \mathrm{MeV}$ D-D Neutron Generator treatment room using MCNPX computer code. The BNCT neutron source used in this research is a neutron Beam Shaping Assembly model which has been designed with a specification as shown in Figure 2 [17].

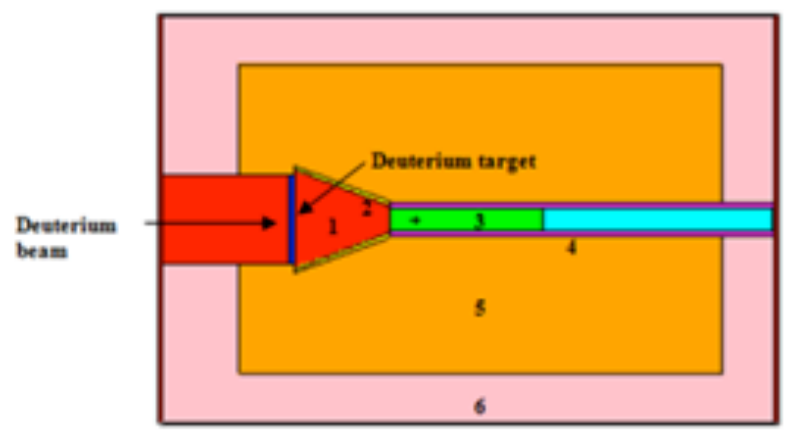

Figure 2. Beam Shaping Assembly

The BSA design uses a collimator with air material and Nickel $(\mathrm{Ni})$ while the reflector uses elements of $\mathrm{Pb}$ and paraffin. For Gamma shield, material bismuth (Bi) is used. The moderator material is AlF3. All of the calculations and modelings in this research were conducted using Monte Carlo N-Partical eXtended (MCNPX). The MCNPX computer code is a particle transport code with a powerful three dimensional geometry and source modeling capabilities that can be applied to reactor physics, shielding, criticality, environmental nuclear waste cleanup, medical imaging, and numerous other related areas. To display the geometry of the MCNPX code especially for treatment room modeling, we used Visual Editor. The Visual Editor allows the user to easily set up and modify the view of the MCNP/MCNPX geometry and to determine model information directly from the plot window. The Visual Editor also allows the user to interactively create an input file with the help of two or more dynamic cross sectional views of the model. The input file can also be created in an external editor (such as WordPad or Microsoft Word) or by typing (editing) the file in the Input window in the Visual Editor.

The second step of this research was to varying the shielding materials. Four materials have been selected to be simulated as shielding materials such as paraffin, barite concrete, lead and polyethylene. Each material then were tested as the shielding material with various thicknes $(10-$ $100 \mathrm{~cm}$ ), then the radiation dose rates were calculated for each shielding material and thicknes variation using F4 tally in MCNPX. All shielding materials then were compared against one another to find out the best one for shielding material which is only passed low radiation dose rate to the outer side of the treatment room shielding.

In the last step we combined selected materials as the shielding materials. Then the dose rate of outside the treatment room was calculated using MCNPX computer code. The optimized thickness of shields and their materials are determined in such a way that the equivalent dose rate delivered outsides the shields would be lower than the maximum allowable dose rate that is recommended by BAPETEN. Neutron and photon dose rates were determined by calculating 
particle flux on fictitious regions across a bulk concrete shield by F4 tally in MCNPX and using ANSI/ANS-6.1.1 flux-to-dose conversion factors.

\section{RESULTS AND DISCUSSION}

First step of this research was modeling a BNCT Based on 2.4 MeV D-D Neutron Generator facility using MCNPX computer code. The code was written in notepad and the geometry visualitation was performed using Visual Editor. The treatment room modeled with $200 \mathrm{~cm}$ in length, a width of $200 \mathrm{~cm}$, and a height of $166.4 \mathrm{~cm}$ adapted to the in vitro and in vivo tests of BNCT Facility. It is consists of five parts as the treatment room shielding i.e.: front side; upper side; bottom side; left side; and right side. On the back side, it is located a $2.4 \mathrm{MeV}$ D-D as the neutron sources for this BNCT facility system. The results of this work are displayed on the Figure 1.

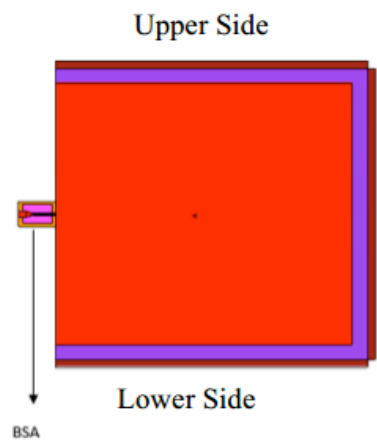

(a)

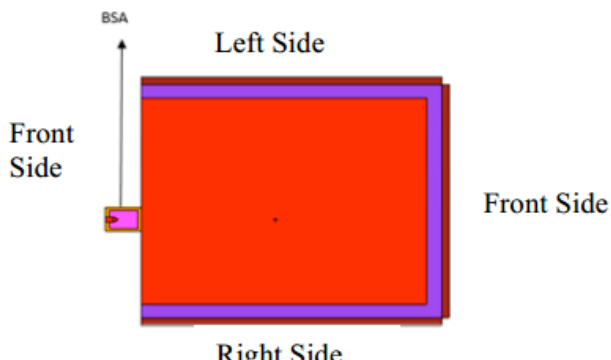

(b)

Air

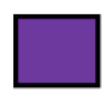

Soft Tissue

Figure 3. BNCT Facility shielding model:

(a). Side View (b) Top View (in $\mathrm{cm}$ ).

Material variation for BNCT Based on D-D of treatment room facility radiation shielding was performed using MCNPX computer code. Baryte concrete, Parrafin, Borated Polyethylene and Lead were used as shielding materials. Figure 4 to figure 8 show the dose rate in all five parts of the treatment room models (lower, upper, left, right and front side) as shown in Figure 3.

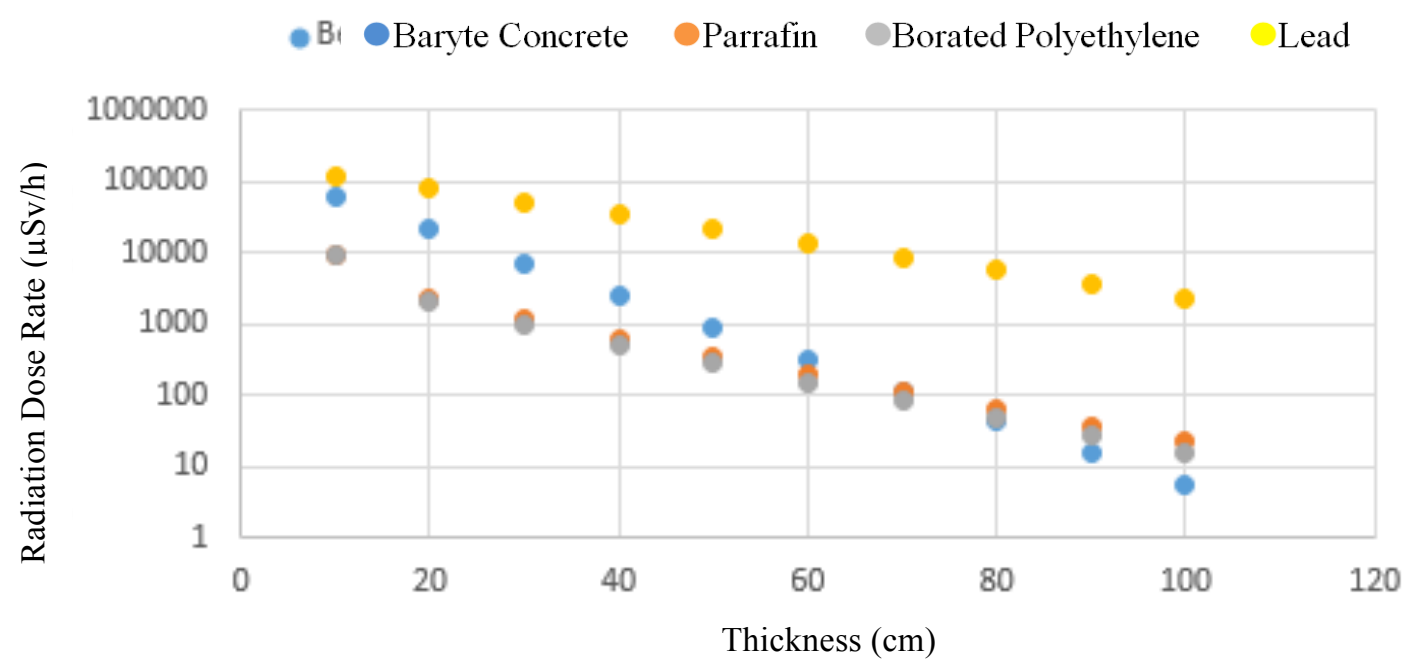

Figure 4. Radiation dose rate in the upper side of the treatment room shielding 


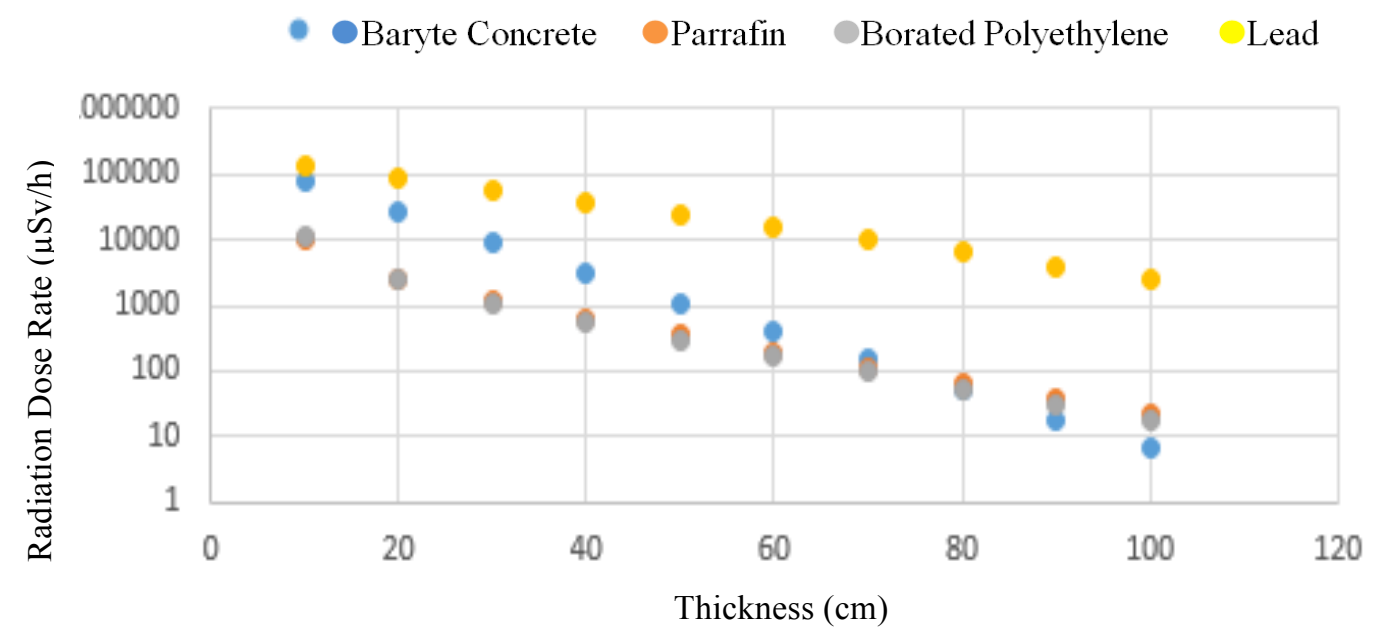

Figure 5. Radiation dose rate in the bottom side of the treatment room shielding

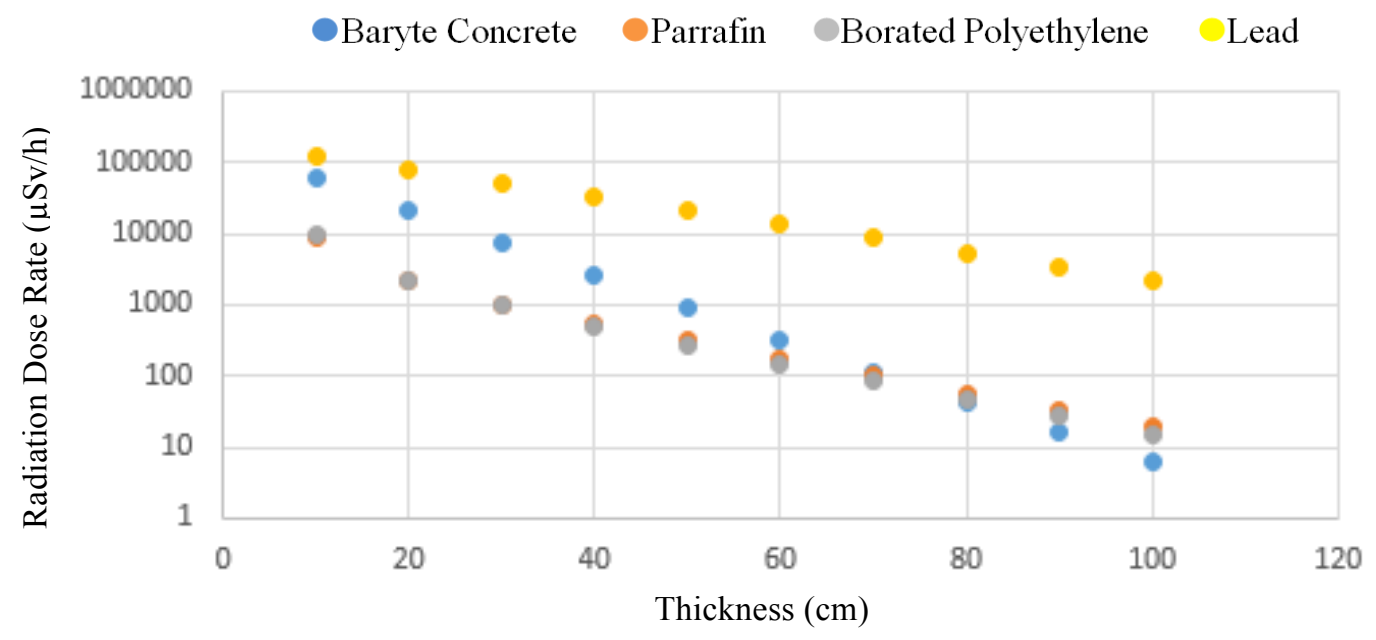

Figure 6. Radiation dose rate in the left side of the treatment room shielding 


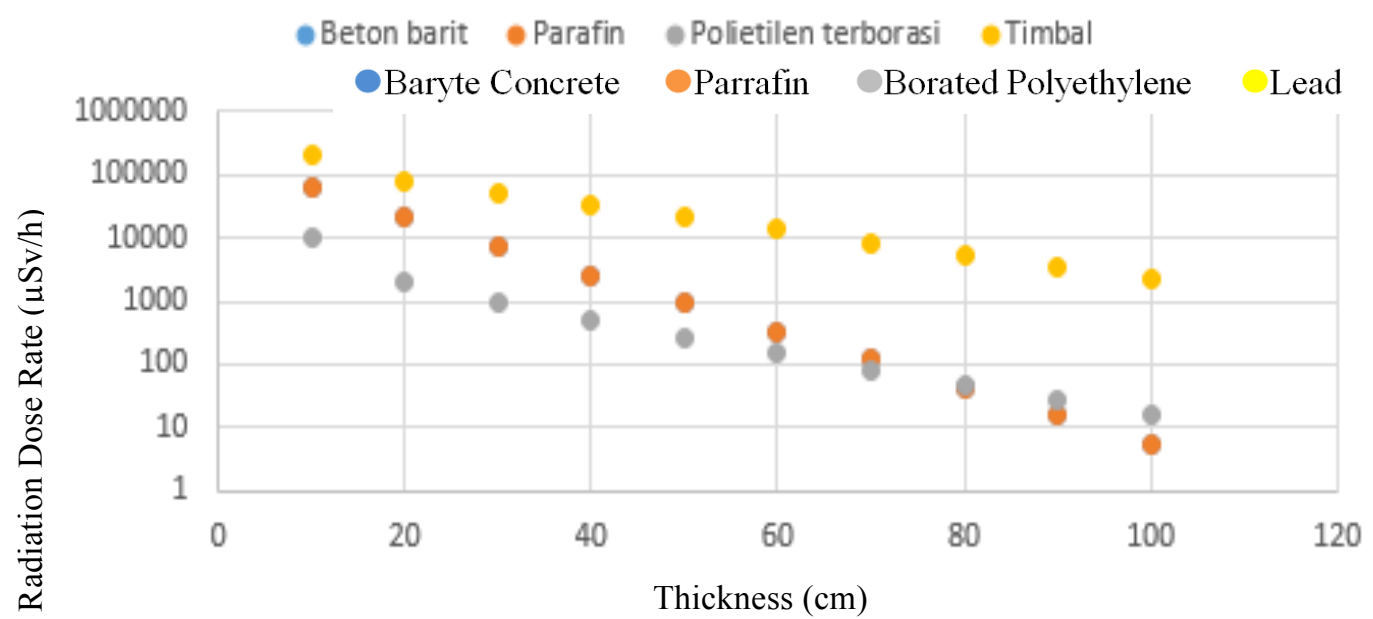

Figure 7. Radiation dose rate in the right side of the treatment room shielding

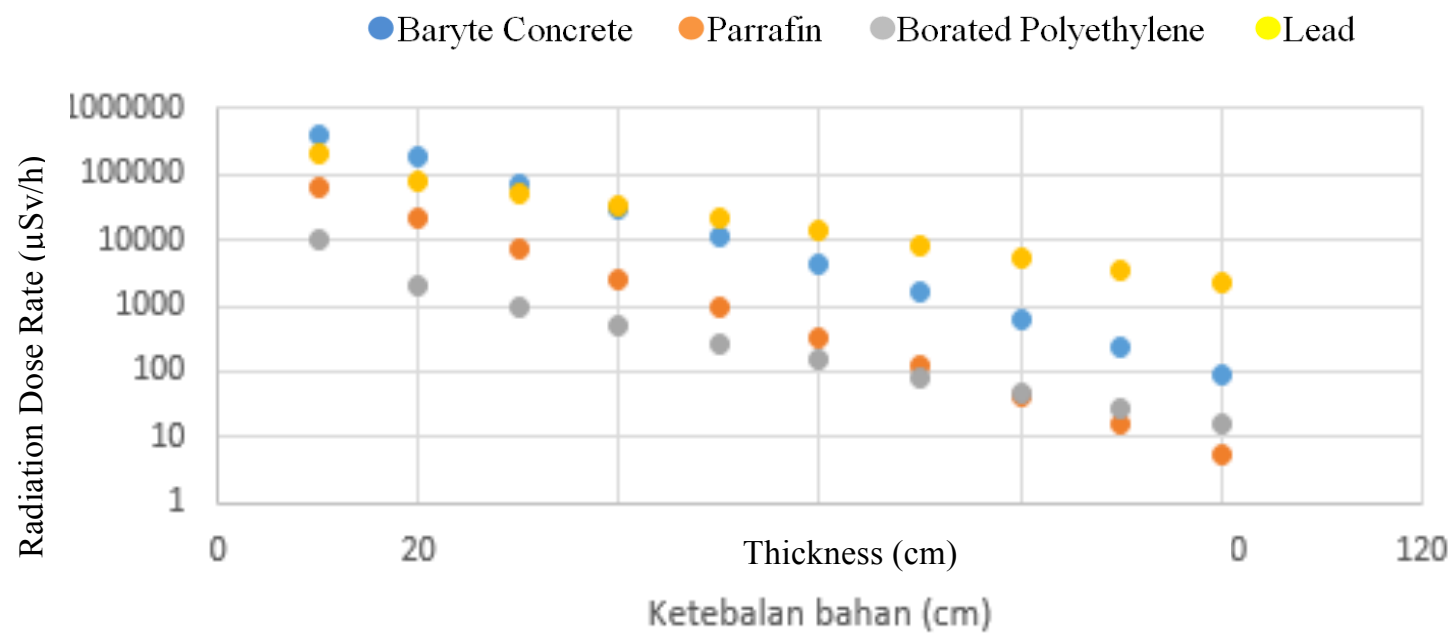

Figure 8. Radiation dose rate in the front side of the treatment room shielding

Allmost all sides of treatment room model show the same radiation dose rate characteristics. Barite concrete, paraffin and borated polyethylene are the most effective materials as the radiation shielding which only pass the radiation dose rate lower than $100 \mu \mathrm{Sv} / \mathrm{h}$ in $100 \mathrm{~cm}$ thickness. Furthermore, lead passes high radiation dose rate (higher than $1000 \mu \mathrm{Sv} / \mathrm{h}$ in $100 \mathrm{~cm}$ thickness). Hence, barite concrete, paraffin and borated polyethylene were selected as BNCT based on D-D treatment room shielding materials on this research. All selected materials then were compared against each other in four treatment room designs.

Design 1 (Figure 5) uses $90 \mathrm{~cm}$ barrels of concrete and $40 \mathrm{~cm}$ of polymerization as the main layer. Additional layers of $10 \mathrm{~cm}$ barrels of concrete and polyethylene are divided to10 $\mathrm{cm}$ in thickness for each layer with a smaller volume. 


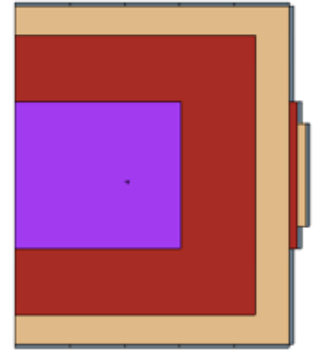

(a)

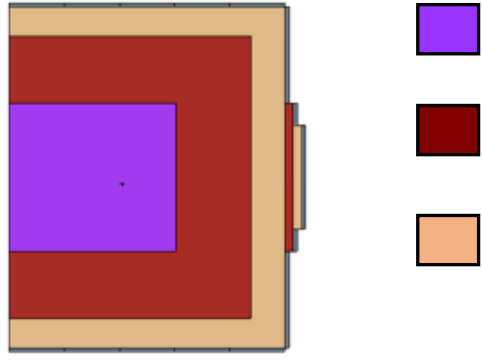

AirBarite

Concrete

Borated Polyethylene

Figure 9. Design of radiation shield with barite concrete and borated polyethylene Material

(a) Side View (b) Top ViewDesign 2 (Figure 6) uses $90 \mathrm{~cm}$ barit concrete material and $40 \mathrm{~cm}$ paraffin as the main layer. Additional layers of $10 \mathrm{~cm}$ barrels of concrete and polyethylene are divided to $10 \mathrm{~cm}$ in thickness for each layer with a smaller volume.

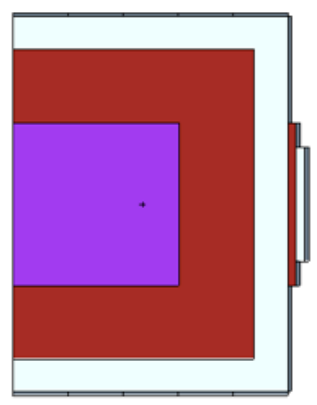

(a)

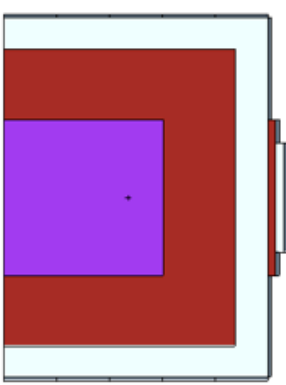

(b)
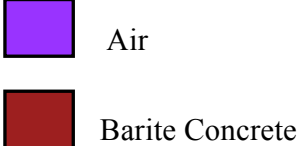

$\square$ Parafin

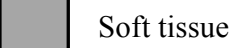

Figure 10. Design of Radiation Shield with Barite and Paraffin Concrete Material

$$
\text { (a) Side View (b) Top View }
$$

Design 3 (Figure 7) uses $100 \mathrm{~cm}$ barrels of concrete and $40 \mathrm{~cm}$ of polymerization as the main layer. Additional layers of $10 \mathrm{~cm}$ barrels of concrete and polyethylene are divided to $10 \mathrm{~cm}$ in thickness for each layer with a smaller volume.

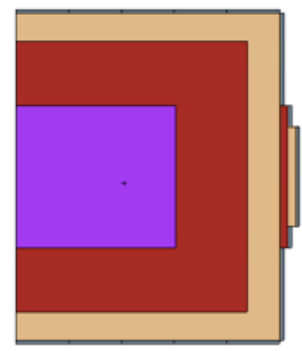

(a)

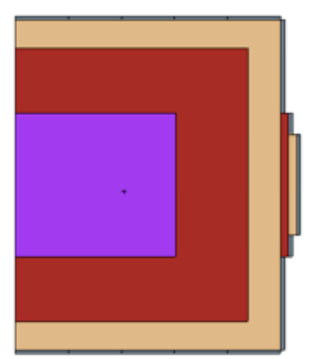

(b)

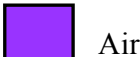

Barite Concrete

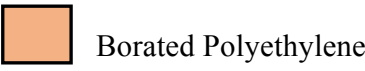

Soft tissue

Figure 11. Design of Radiation Shield with Barite Concrete and Borated Polyethylene Material (a) Side View (b) Top View

Design 4 (Figure 8) uses a material of $100 \mathrm{~cm}$ barrel concrete and $40 \mathrm{~cm}$ paraffin as the main layer. Additional layers of $10 \mathrm{~cm}$ barrels of concrete and polyethylene are divided to10 $\mathrm{cm}$ in thickness for each layer with a smaller volume. 


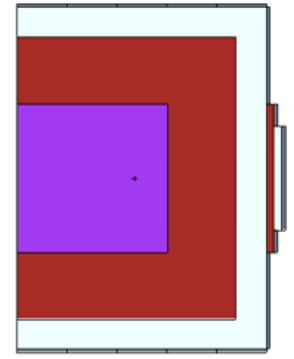

(a)
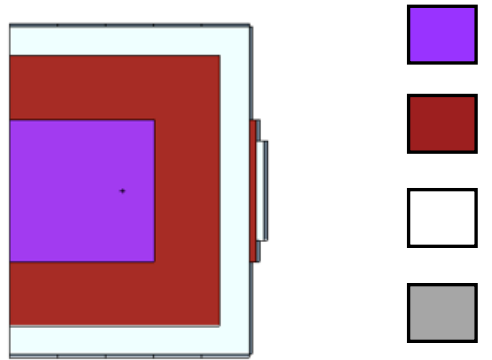

Air

Barite Concrete

Paraffin

Soft tissue

Figure 12. Design of Radiation Shield with Barite and Paraffin Concrete Material

(a) Side View (b) Top View

The previous four radiation shield designs meet the upper limit value of the allowed radiation dose of $10 \mu \mathrm{Sv} / \mathrm{h}$. The most optimal radiation shielding model was chosen from the radiation shield options based on the highest leak rate of radiation dose on each radiation shield design, as well as the average leakage rate of the radiation dose.

Table 1. Radiation dose summary of the four radiation shielding designs

\begin{tabular}{ccccc}
\hline & Design 1 & Design 2 & Design 3 & Design 4 \\
\hline $\begin{array}{l}\text { The largest dose } \\
\text { rate }(\mu \mathrm{S} \text { /hour })\end{array}$ & 5.62 & 7.18 & 4.58 & 4.75 \\
$\begin{array}{c}\text { Average dose } \\
\text { rate }(\mu \mathrm{Sv} / \text { hour })\end{array}$ & 1.408 & 1.512 & 0.65 & 0.683 \\
\hline
\end{tabular}

The simulation calculations of each design (Table 2) indicate that the entire radiation designs meet the BAPETEN regulation for radiation workers lethal dose which is the radiation dose not exceeding than $10 \mu \mathrm{Sv} / \mathrm{h}$. Design 3 has the smallest radiation dose rate and smallest average dose rate. Therefore, design 3 is proposed as the great design for the BNCT based on D-D treatment room shielding on this research.

\section{CONCLUSION}

The best materials to be used as a radiation shield at 10-70 $\mathrm{cm}$ thickness are parafin and borated polyethylene, while at the thickness of $80-100 \mathrm{~cm}$ the best material is baryte concrete. The best design of the four designs that have been made is the third design composed of spun polyetylene and baryte concrete with a maximum dose rate of $4.58 \mu \mathrm{Sv} /$ hour and the average radiation dose rate of $0.65 \mu \mathrm{Sv} /$ hour. The dose rates are lower than the lethal dose that is allowed by BAPETEN regulation for radiation workers lethal dose.

\section{ACKNOWLEDGMENT}

The authors would like to express their thanks to those who took role for the accomplishment of the project, especially for Dr. Andang Widi Harto as the Lecturer at Department of Nuclear Engineering of Gadjah Mada University and Dr. Susilo Widodo as the Head of Centre for Accaelerator Science and Technology - National Nuclear Energy Agency (PSTA-BATAN) for the opportunity given to do this work. 


\section{REFERENCES}

1. World Health Organization. Programmes and projects, Cancer, 2017. Available from: http://www.who.int/cancer/en/. Last accessed 08 January 2017

2. As Ferlay J, Soerjomataram I, Ervik M, Dikshit R, Eser S, Mathers C et al. GLOBOCAN 2012 v1.0, Cancer Incidence and Mortality Worldwide: IARC CancerBase No. 11 [website]. Lyon, France: International Agency for Research on Cancer; 2013 (http://globocan.iarc.fr/old/bar_site.as, accessed 9 January 2017)

3. K. K. Das et al., "Pediatric glioblastoma: clinico-radiological profile and factors affecting the outcome," Child's Nervous System, vol. 28, no. 12, pp. 2055-2062, Dec. 2012.

4. Jenkins P.A. Boron Neutron Capture Therapy for Her2+ Breast Cancers: A Feasibility Study Evaluating BNCT for Potential Role in Breast Conservation Therapies, A Dissertation, Department of Civil and Environmental Engineering, Utah: The University of Utah; 2012.

5. Andoh, T., Fujimoto, T., Sudo, T., Suzuki, MM., Sakurai, Y., Sakuma, T., Moritake, H., Sugimoto, T., Takeuchi, T., Sonobe, H., Epstein, A.L., Fukumori, Y., Ono, K., Ichikawa, H. Boron neutron capture therapy, as a new treatment for clear cell sarcoma: Trial on different animal model, Applied Radiation and Isotopes. 2014. 88: 59-63.

6. Aihara, T., Morita, N., Kamitani, N., Kumada, H., Ono, K., Hiratsuka, J., Harada, T. BNCT for advanced or recurrent head andneck cancer. Applied Radiation and Isotopes. 2014. 88: 12-15.

7. Capoulat, M.E., Minsky, D.M., Kreiner, A.J. Computational assessment of deepseated tumor treatment capability of the ${ }^{9} \mathrm{Be}(\mathrm{d}, \mathrm{n})^{10} \mathrm{~B}$ reaction for acceleratorbased Boron Neutron Capture Therapy (ABBNCT). PhysicaMedica. 2014. 30: 133-146.

8. MIT. The Basics of Boron Neutron Capture Therapy [Accessed: 1 November 2016]. Available from: http://web.mit.edu/nrl/www/bnct/info/description/description.html.

9. Ardana IM., Kusminarto, Sardjono Y. Optimization of a Beam Shaping Assembly Design for Boron Neutron Capture Cancer Therapy Facility Based on $30 \mathrm{MeV}$ Cyclotron. Indonesian Journal of Physics and Nuclear Applications. 2016. 1(3):128-137.

10. Wicaksono A.S., Harto A.W., Sardjono Y. Internal Dose Analysis for Radiation Worker in Cancer Therapy Based on Boron Neutron Capture Cancer Therapy with Neutron Source Cyclotron $30 \mathrm{MeV}$. Indonesian Journal of Physics and Nuclear Applications. 2017. 2(2):91-100.

11. Priambodo G., Nugroho F., Palupi D.S., Zailani R., and Sardjono Y. Optimization of Biological Shield for Boron Neutron Capture Therapy (BNCT) at Kartini Research Reactor. Jurnal Teknologi Reaktor Nuklir Tri Dasa Mega. 2017. 19(3):139-148

12. Nirmalasari Y.D., Soeparmi, Sardjono Y. Analysis of Safety and Health of Radiation Officer at Pilot Plant BNCT. Indonesian Journal of Physics and Nuclear Applications. 2017. 2(1):42-46.

13. Dwiputra M.IM.A., Harto A.W., Sardjono Y. Shield Modelling of Boron Neutron Capture Therapy with Kartini Reactor's Thermal Coloumn as Neutron Source using MCNPX. Indonesian Journal of Physics and Nuclear Applications. 2016. 1(1):44-53.

14. Pouryavi M., Masoudi S.F., and Rahmani F. Radiation Shielding Design of BNCT Treatment Room for D-T Neutron Source. Applied Radiation and Isotopes. 2015. 99:9096.

15. Pasaribu R., Kusminarto, Sardjono Y. Clinical Trial Design of Boron Neutron Capture Therapy on Breast Cancer using D-D Coaxial Compact Neutron Generator as Neutron Source and Monte Carlo N-Particle Simulation Method. Indonesian Journal of Physics and Nuclear Applications. 2016. 1(1):34-43. 
16. Susilowati A.D., Kusminarto, Sardjono Y. Boron Neutron Capture Therapy (BNCT) using Compact Neutron Generator. Indonesian Journal of Physics and Nuclear Applications. 2016. 1(2):73-80.

17. Isyan P., Harto A.W., Sardjono Y. Conceptual Design of Collimator at Boron Neutron Capture Therapy Facility with $30 \mathrm{MeV}$ Cyclotron. Indonesian Journal of Physics and Nuclear Applications. 2017. 2(1):47-53. 